\title{
Targeting Adenosine Receptors for the Treatment of Melanoma
}

\author{
Sarvesh Jajoo, Sandeep Sheth, \\ Debashree Mukherjea, Leonard P. Rybak and Vickram Ramkumar \\ Southern Illinois University School of Medicine, Springfield, IL
}

USA

\section{Introduction}

Melanoma is the malignant tumor of melanocytes, skin cells which produce the pigment melanin. According to the 2010 statistics from American Cancer Society, around 68,130 new cases will be diagnosed with melanoma, of which 8,700 individuals will die (http://www.cancer.gov/cancertopics/types/melanoma). Melanoma is one of the most fatal forms of skin cancer, accounting for almost $65 \%$ of all the skin cancer related deaths. Despite a decrease in the mortality rate in the population under the age of 65 years, the incidence of melanoma has increased annually in both Caucasian men and women. It is ranked as the $5^{\text {th }}$ most common cancer in men and the $6^{\text {th }}$ most common cancer in women (Sober et al., 2008). Additionally, the 5-year survival for the metastatic melanoma is still significantly high, when compared to the non-metastatic type (O'Day et al., 2002). This is due, in part, to the relative resistance of metastatic melanoma to chemotherapeutic agents (O'Day et al., 2002). Thus, it is essential to develop new therapeutic agents targeting unique molecular signaling pathways important for the development of the malignant and invasive neoplasm.

Factors which predispose individual to developing melanomas include, among others, exposure to sunlight (UVB irradiation) (Lee, 1982). UVB radiation is linked to DNA damage and depressed immune function. This is supported by demographic data which show high prevalence of melanomas in white skin individuals living in the equatorial zone (compared to those living in northern latitudes) (Lee and Scotto, 1993), the prevalence of melanomas to sun exposed areas of the body, early exposures and sunburns, and increased outdoor recreational sports (Balch et al., 1997). However, sunlight may not be the only cause, but one of several causes. For example, the incidence of melanomas is higher in white collar workers (mostly likely to work inside) than in blue collar workers (more likely to work outside). Susceptibility to sunburns, light skin color and freckling are associated with increased incidence of melanomas (Balch et al., 1997). Measures which could be taken to decrease the incidence of melanomas include the use of UV-A/UV-B sunblock with sun protection factor $\geq 15$, avoiding mid-day sunlight, restriction of activity in a shaded area, and the use of umbrellas and protective clothing. In addition, it is also recommended that individuals avoid tanning in a UV tanning salon (Balch et al., 1997).

Several genes have been identified which increases susceptibility to melanomas. These include p16, the product of which regulates the cell cycle by inhibiting cyclin-dependent 
kinase 4 (cdk4) (Serrano et al., 1993). Mutation of this gene would allow for uncontrolled cell proliferation. Screening could identify patients who are likely to develop melanoma and help them to institute life-style changes to limit UV exposure.

Melanoma progresses from a common acquired nevus to a primary dysplastic nevus. This can then develop into a primary melanoma and subsequently to metastatic melanoma. Early detection of melanoma is essential for initiation of its management. This is aided by evaluation of antigenic markers linked to differentiation and pathogenesis. One such protein, S-100 protein, is expressed in all melanomas and could serve as a marker for melanoma (Harpio and Einarsson, 2004). However, it is also expressed in sarcomas and other cancers. Another protein, HMB-45, is more specific for melanoma but is not always accurate for metastatic melanoma (Wick et al., 1988). Various other markers include cytokeratins and leukocyte common antigen.

Management of melanoma includes surgical excision of the superficial skin lesions and local metastases which are accessible. In addition, radiation of cutaneous and lymph node metastases could be performed. Chemotherapy is also useful for the management of melanoma. The infusion of the alkylating agent, decarbazine, is a standard treatment. Other agents include melphalan, nitrosureas, platinum compounds, vincristine and others. However, the response rates of chemotherapy are low, ranging from $10-23 \%$. In some cases, limb perfusion with melphalan alone or in combination with immune modulators, such as tumor necrosis factor- $\alpha$ (TNF- $\alpha$ ) and interferons (IFNs) have been shown to be effective. However, the prolonged use of IFNs is limited by the development of flu-like symptoms and hepatotoxicity (Atallah and Flaherty, 2005). Other forms of immunotherapy, such as the use of tumor vaccines and monoclonal antibodies, are under investigation (Weber, 2011). Melanomas are associated with specific antigens on their cell surfaces, which serve as homing targets of cytotoxic T cells (CTLs). These include MAGE-1 (Van der Bruggen et al., 1991; De Plaen et al., 1994), which could be a suitable target for immune-based therapies (Marchand et al., 1993). Other targets include tyrosinase and MART-1 melanoma antigens (Kawakami and Rosenberg, 1996). CTLs generated against these proteins could serve as novel targets for immunotherapy.

This chapter provides a review of studies on the types of adenosine receptors present on melanoma cells and discusses how these receptors mediate the progression or inhibit the growth and metastasis of melanoma. These receptors present on melanoma cells or immune cells mediate a direct or indirect effect on the growth and metastasis of melanoma. Selective agonists or antagonists of these receptor types could serve as novel treatments for melanoma.

\section{Adenosine and its receptors}

Adenosine is a purine nucleoside composed of adenine attached to a ribose molecule via glycosidic linkage. It is a ubiquitously produced by stepwise dephosphorylation of ATP. Extracellular adenosine acts as a signaling molecule which mediates a number of physiological and metabolic effects (Gorlach, 2005). Adenosine accumulation during ischemia and inflammation protects tissue from injury (Linden, 2001). Some effects of adenosine which are considered tissue or cytoprotective are mediated by a variety of cellular mechanisms. These include stimulation of glycogen breakdown to provide glucose for ATP production via anaerobic glycolysis, reduction in neuronal excitability as well as neurotransmitter release to reduce neuronal energy demands (Gorlach, 2005), increasing the 
ratio of oxygen supply to demand by causing vasodilation, reducing inflammation and promoting angiogenesis (Adair, 2005; Jacobson and Gao, 2006).

The idea that adenosine has an important role in cardiovascular function was first introduced more than 80 years ago when Drury and Szent-Gyorgyi (1929) found that extracts from heart and other tissues produced vasodilation, hypotension, bradycardia, and a decrease in atrioventricular conduction velocity. It was later shown by Berne et al (1983) that adenosine acts as a retaliatory metabolite which tend to counter the processes which led to increased oxygen demand. This action helps to maintain tissue oxygenation within a normal range in hypoxia. Such a retaliatory action could be demonstrated in the heart, brain, and skeletal muscle, where adenosine increases oxygen supply by promoting vasodilation and increased blood flow to these tissues (Berne et al., 1983). Adenosine also mediates an antiadrenergic effect which decreases oxygen demand in the heart (Adair, 2005). While these actions of adenosine are relatively short-term, the nucleoside can also promote long-term changes to enhance survival. For example, adenosine promotes angiogenesis, a process of new blood vessel growth (Adair, 2005). Angiogenesis may be important in coronary artery disease, ischemia, stroke and in delayed wound healing for the repair and regeneration of tissue (Gupta and Zhang, 2005). Such an action may also provide oxygen and nutrient to tumors as they grow away from their primary blood vessel supplies.

\subsection{Adenosine: Formation and metabolism}

Adenosine accumulates in tissues when oxygen demand exceeds oxygen supply, as would be encountered during vigorous exercise or during an ischemic attack (Adair, 2005) or in the microenvironment of tumors. It is generated and metabolized through stepwise dephosphorylation of ATP (Figure 1). ATP and ADP are converted by CD39 (ecto-ATP apyrase) to AMP through a process activated by hypoxia (Gorlach, 2005). Dephosphorylation of AMP is mediated intracellularly by cytosolic-5'-nucleotidase and extracellularly by membrane-bound ecto-5'-nucleotidase (CD73), respectively. Intracellularly, adenosine is also produced from the hydrolysis of S-adenosylhomocysteine (SAH). However, hydrolysis of SAH to adenosine contributes marginally to its production (Adair, 2005). Adenosine deaminase is widely distributed in many cells and tissues where it metabolizes adenosine to form inosine and hypoxanthine. Adenosine kinase catalyses the formation of AMP from adenosine in order to replenish the stores of cellular ATP (Adair, 2005; Gorlach, 2005).

The cellular uptake and release of adenosine is accomplished by two main groups of membrane nucleoside transporters. Concentrative nucleoside transporter family (SLC28) is found in specialized epithelial tissue and it mediates active $\mathrm{Na}^{+}$-dependent nucleoside transport. Passive nucleoside transport processes are ubiquitous and are mediated by members of the equilibrative nucleoside transporter (ENT) family (SLC29) (Baldwin et al., 2004). ENTs are bidirectional and four ENT isoforms are identified in human and rodent genome. Inhibition of ENTs by dipyridamole, a coronary vasodilatory and cardio-protective agent, prevents the reuptake of adenosine into the endothelial cells, increases its extracellular concentration and thus enhances AR activation (Adair, 2005; Gorlach, 2005). Thus, extracellular adenosine concentrations can increase by increasing the activities of nucleotidases (major pathway) and adenosine kinases (minor pathway) along with their substrates (such as AMP). In addition, inhibition of ENTs would also lead to increased extracellular adenosine (Adair, 2005). Exposing cells to a hypoxic environment can increase 
the activities of nucleotidases and decrease the activities of adenosine kinases, leading to a net increase in the production of adenosine (Linden, 2001). The induction of ecto-5'nucleotidase (CD73) activity in hypoxic condition has been shown in the ischemic heart (Minamino et al., 1996) and brain (Braun et al., 1997) of intact animal, possibly by hypoxia inducible factor (HIF-1- dependent pathway (Synnestvedt et al., 2002). Hypoxia also downregulates ENT1 expression in different mouse tissues (Chaudry et al., 2004; Eltzschig et al., 2005), thereby increasing extracellular concentrations of adenosine.

Higher adenosine concentrations in the extracellular fluids are important to activate the ARs present on a variety of cells. Studies have estimated the physiological extracellular adenosine concentrations in normal brain to be approximately 30-300 nM (Fredholm et al., 2001). In vivo studies by Blay et al. (1997) revealed that the adenosine concentrations in the extracellular fluids of solid tumor in mice range from $0.2-2.4 \mu \mathrm{M}$, which is 10 - to 20 -fold higher compared to concentrations in adjacent subcutaneous tissue. Furthermore, treatment with inhibitors of adenosine deaminase and adenosine kinase can increase adenosine levels in tumors to as high as $13 \mu \mathrm{M}$ (Blay et al., 1997).

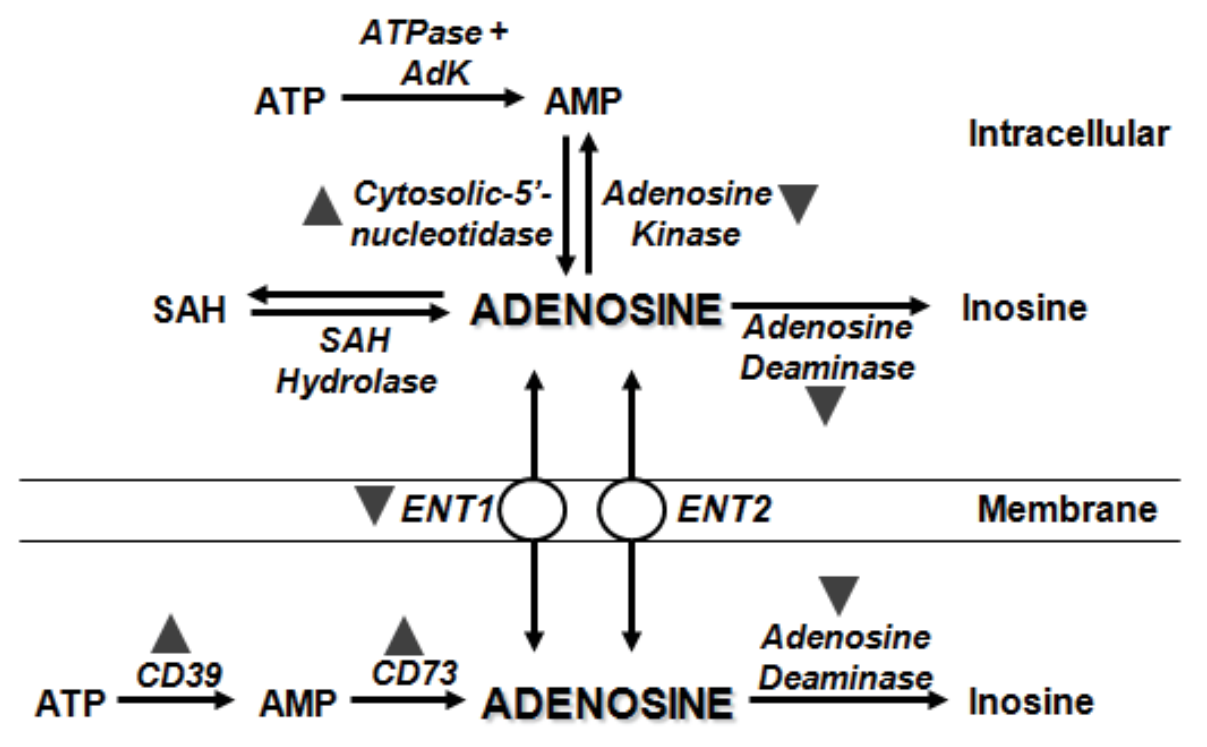

Extracellular

Fig. 1. Metabolic pathways for adenosine production and consumption. Adenosine is produced by the dephosphorylation of ATP and ADP by ATPases and the action of 5 '-nucleotidase. Additionally, the nucleoside is produced from SAH by SAH hydrolase. Once produced, adenosine could be transported in or out of the cell by bidirectional transporters , ENT1 and 2. Adenosine is rapidly degraded by adenosine deaminase. Abbreviations: ATPase, ATP hydrolyzing enzymes; AdK, adenylate kinase; SAH, S-adenosylhomocysteine; ENT: Equilibrative nucleoside transporter. The arrow heads and indicate up-regulation or down-regulation of enzymes and the transporter during hypoxia. [Modified from (Adair, 2005; Gorlach, 2005)] 


\subsection{Adenosine receptors}

Studies have shown that adenosine levels are highest in the tumor microenvironment which is severely hypoxic. The physiological concentrations of adenosine produced under such conditions are sufficient enough to activate ARs present on the tumor cells (Ohta et al., 2006). The effects of extracellular adenosine are mediated by four known ARs subtypes, namely the $A_{1}, A_{2 A}, A_{2 B}$ and $A_{3} A R$. All of these ARs are cell surface $G$ protein-coupled receptor which have distinct tissue-specific distributions (Fredholm et al., 2001). These ARs were classified on the basis of their inhibiting $\left(A_{1}\right.$ and $\left.A_{3} A R\right)$ or stimulating $\left(A_{2 A}\right.$ and $\left.A_{2 B} A R\right)$ adenylyl cyclase by coupling to either $G_{i}$ or $G_{s}$ types of guanine nucleotide regulatory $(G)$ proteins, respectively (Fredholm et al., 2006). Inhibition or activation of adenylyl cyclase reduces or increases intracellular cyclic AMP, respectively. This second messenger mediates a number of cellular functions, which could be altered depending on the presence of extracellular adenosine and the AR profile expressed on the cell surface. In addition, there is some evidence that the ARs may signal via other G-proteins (Fredholm et al., 2001), which activate other pathways such as phospholipase $\mathrm{C}$ (PLC), $\mathrm{Ca}^{2+}$ and mitogen-activated protein kinases (MAPKs) (Jacobson and Gao, 2006). Activation of $A_{1} A R$ inhibits adenylyl cyclase by stimulating pertussis toxin-sensitive $G_{i}$ proteins, leading to increased activity of PLC. The $\mathrm{A}_{1} \mathrm{AR}$ is also coupled to the activation of $\mathrm{K}^{+}$channels and inhibition of $\mathrm{N}-, \mathrm{P}$ - and Q-type $\mathrm{Ca}^{2+}$ channels (Fredholm et al., 2001; Jacobson and Gao, 2006). The same appears to be true for $A_{3} A R$, which also binds to $G_{q}$ G-proteins and activates PLC (Fredholm et al., 2001). In contrast, the $A_{2 A} A R$ interacts with the stimulatory $G_{s}$ and $G_{\text {olf }} G$-proteins to activate adenylyl cyclase and increase cyclic AMP concentrations (Fredholm et al., 2001). Activation of $A_{2 A} A R$ also induces the formation of inositol 1,4,5-trisphosphate $\left(\mathrm{IP}_{3}\right)$ to raise intracellular $\mathrm{Ca}^{2+}$ and activate PKC in COS-7 cells via pertussis toxin-insensitive $G_{\alpha 15}$ and $G_{\alpha 16}$ proteins (Fredholm et al., 2001). Like the $A_{2 A} A R$, the $A_{2 B} A R$ is positively coupled to both $G_{s}$ and $G_{q}$ proteins and therefore can modulate both intracellular cyclic $\mathrm{AMP}$ and $\mathrm{IP}_{3}$ concentrations (Fredholm et al., 2001). $A_{2 B} A R$ has lower affinity for adenosine as compared to $A_{2 A} A R$ (Feoktistov and Biaggioni, 1997). A $A_{2 A} A R$ expression could be induced by inflammatory cytokines, such as interleukin (IL)-1 and tumor necrosis factor (TNF)- $\alpha$ (Khoa et al., 2001). $\mathrm{A}_{2 \mathrm{~B}} \mathrm{AR}$ expression is induced by hypoxia inducible factor (HIF)-1a in hypoxia (Kong et al., 2006), TNF- $\alpha$ and interferon (IFN)- $\gamma$ (St Hilaire et al., 2008; Xaus et al., 1999). Such regulations could be important in a tumor microenvironment associated with significant hypoxia and/or inflammation.

Several studies have shown that the adenosine-induced activation of MAPK is essential for mediating cell differentiation, survival, proliferation, and death (Fredholm et al., 2001). Extracellular regulated kinases (ERK1/2) are members of the MAPK family linked to cellular proliferation. A AR transiently expressed in COS-7 cells activated ERK1/2 via $\beta, \gamma^{-}$ subunits released from $G_{i / o}$ G-proteins (Faure et al., 1994). Studies on stably expressed $A_{1} A R$ in $\mathrm{CHO}$ cells demonstrated that the $\mathrm{A}_{1} \mathrm{AR}$ can also induce ERK1/2 activation (Dickenson et al., 1998; Schulte and Fredholm, 2000). A2A AR activation stimulates ERK1/2 via a cyclic

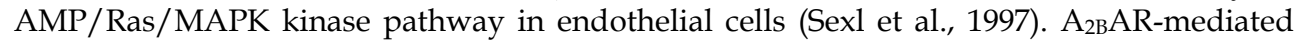
activation of MAPK is important for interleukin (IL)-8 secretion, a pro-angiogenic growth factor, and consequently for mast cell activation (Fredholm et al., 2001). Another pathway has been demonstrated in human umbilical vascular endothelial cell (HUVEC) which involves cyclic AMP-dependent but protein kinase A (PKA)-independent activation of ERK1/2, associated with cell proliferation (Fang and Olah, 2007). The cyclic AMP activation 
of exchange protein activated by cyclic AMP-1 (Epac1) stimulates ERK1/2 activity. This provides an alternate pathway for ERK1/2 activation by the $\mathrm{A}_{2 \mathrm{~B}} \mathrm{AR}$. (Fang and Olah, 2007).

\subsection{Adenosine receptors in cancer}

ARs are differentially expressed on tumor cell lines and tumor samples. High levels of $\mathrm{A}_{1} \mathrm{AR}$ are expressed in breast cancer tissues, compared to normal breast tissues (Mirza et al., 2005). Activation of the $A_{1} A R$ was shown to reduce the proliferation of these cells by inhibiting the $G_{1}$ checkpoint in the cell cycle (Mirza et al., 2005). Increased $A_{1} A R$ was also observed in the peritumoral regions of experimental F98 glioma cells. The sources of the increased $\mathrm{A}_{1} \mathrm{AR}$ expression were activated astrocytes and microglia which suppress glioblastoma (Synowitz et al., 2006). In addition, activation of $\mathrm{A}_{1} \mathrm{AR}$ on colon cancer cells increased apoptosis by activating caspases (Saito et al., 2010). Studies have also shown an anti-tumor action of $\mathrm{A}_{2 \mathrm{~A}} \mathrm{AR}$ in A375 melanoma (Merighi et al., 2002) and human colon cancer cells (Yasuda et al., 2009), the latter mediated by activation of caspases. In contrast, the $\mathrm{A}_{2 \mathrm{~A}} \mathrm{AR}$ promotes growth of breast cancer MCF-7 breast cancer cells (Etique et al., 2009) and increases angiogenesis by inducing VEGF expression (Montesinos et al., 2002). These studies suggest that $\mathrm{A}_{2 \mathrm{~A}} \mathrm{AR}$ antagonists could be useful in cancer by blocking angiogenesis. Activation of the $\mathrm{A}_{2 \mathrm{~B}} \mathrm{AR}$ is also linked to angiogenesis and promotes growth and tumor metastasis (Grant et al., 1999). In support of this, $A_{2 B} A R$ knockout mice, administered Lewis lung carcinoma, demonstrated reduced tumor growth and survival times (Ryzhov et al., 2008). Studies performed on U87 MG human glioblastoma cells only detected transcripts for $A_{1}, A_{2 A}$ and $A_{2 B} A R s$, but no transcript for $A_{3} A R$ (Zeng et al., 2003). However, Merighi et al. (2006) were able to detect $A_{3} A R$ in these cells. $A_{3} A R$ is also highly expressed in tumors like colon and breast carcinoma tissues as compared to non-neoplastic or normal tisues (Madi et al., 2004). A role of the $A_{3} A R$ in mediating anti-tumor actions in vitro and in vivo has been demonstrated. For example, $\mathrm{A}_{3} \mathrm{AR}$ agonists inhibit the growth of melanoma (Madi et al., 2003), colon (Ohana et al., 2003) and prostate cancers (Fishman et al., 2004) in animal models. Induction of the $A_{3} A R$ occurs in several types of cancers (Madi et al., 2004), when compared to normal adjacent tissue, suggesting that these receptors could serve as potential molecular markers of these cancers. One study demonstrated inhibition of liver metastasis in mice inoculated with human HCT-116 or murine CT-26 colon carcinoma cells by $\mathrm{A}_{3} \mathrm{AR}$ agonists (Ohana et al., 2003). The anti-tumor action of $A_{3} A R$ agonists could be explained by an increase in natural killer (NK) cell activity, which promotes killing of tumor cells (Harish et al., 2003).

\section{Adenosine receptors in melanoma}

Studies have demonstrated both pro- and anti-tumorigenic effects of AR activation in melanoma. Early studies showed that topical application of an $\mathrm{A}_{2 \mathrm{~A}} \mathrm{AR}$ agonist to the skin enhanced wound closure in animals as well as in the animals (Montesinos et al., 1997). Adenosine suppressed the proliferation of transformed keratinocytes in both $G_{1}$ and $S$ phases of the cell cycle (Brown et al., 2000). Furthermore, activation of $\mathrm{A}_{3} \mathrm{AR}$ protected skin mast cells from UV light-induced cell death (Gao et al., 2001). This suggests that $A_{3} A R$ agonists can also mediate similar protection in different skin cell types. Studies described below demonstrate the actions of different AR subtypes on melanoma and support the utility of these receptor for treating melanoma. These receptors are described in order of their importance in melanoma treatment. 


\section{1 $\mathrm{A}_{3}$ adenosine receptors and melanoma}

The actions of this AR subtype has been best studied in melanoma. This receptor is highly expressed in melanoma cell lines and tissues, compared to normal tissues. Measurements of the mRNA levels of $A_{3} A R$ in paraffin-embedded melanoma tissue slides showed almost 2fold increased expression of $\mathrm{A}_{3} \mathrm{AR}$ in cancerous tissues, as compared to the normal tissues (Madi et al., 2004). Human malignant melanoma A375 cells expressed high levels of $A_{3} A R$, as determined by radioligand binding assays. Activation of these receptors did not decrease forskolin-stimulated adenylyl cyclase activity (Merighi et al., 2001), suggesting coupling of these receptors to an alternate signaling system. In fact, $A_{3} A R$ activation increased intracellular calcium release which was suppressed by an $A_{3} A R$ antagonist. This finding suggests that $A_{3} A R$ preferentially couples to a $G_{q}$-PLC pathway in A375 melanoma cells. Activation of $\mathrm{A}_{3} \mathrm{ARs}$ in these cells improved survival and reduced $\mathrm{A}_{2 \mathrm{~A}} \mathrm{AR}$-induced cell death. However, $\mathrm{A}_{3} \mathrm{AR}$ agonist decreased melanoma cell proliferation in a PKC- and MAPKdependent manner. Furthermore, $A_{3} A R$ activation arrested cells in the $G_{1}$ phase, leading to decreased cell number in the $\mathrm{G}_{2} / \mathrm{M}$ phase (Merighi et al., 2002). The reason for the apparent discrepancy between improving survival and decreasing cell proliferation following $\mathrm{A}_{3} \mathrm{AR}$ activation in A375 melanoma cells is unclear.

In an earlier study, Bar-Yehuda et al. (2001) showed that the $A_{3} A R$ agonist, 1-deoxy1-[6-[((3-iodophenyl)methyl)amino]-9H-purin-9-yl]-N-methyl- $\beta$-D-ribofuranuronamide, N6(3-iodobenzyl)adenosine-5'-N-methyluronamide (IB-MECA), inhibited the growth of murine melanoma (B16-F10) cells in culture and suppressed the tumor growth in mice injected with these cells. B16-F10 melanoma cells express high levels of $\mathrm{A}_{3} \mathrm{AR}$, as detected by western blotting, immunocytochemistry and RT-PCR (Madi et al., 2003). The authors showed that the $\mathrm{A}_{3} \mathrm{AR}$ in these cells were negatively coupled to adenylyl cyclase and reduced PKA activity. In addition to the primary melanoma growth, the $\mathrm{A}_{3} \mathrm{AR}$ agonist reduced the number of metastatic lung foci, suggesting that $A_{3} A R$ activation also suppresses metastasis of these cells. There was also an additive effect of $\mathrm{A}_{3} \mathrm{AR}$ agonist and cyclophosphamide, a chemotherapeutic drug (Fishman et al., 2001). $\mathrm{A}_{3} \mathrm{AR}$ expression has also been studied in another murine melanoma cell line (B16-BL6). Cordycepin, a product of the parasitic fungus, Cordyceps sinensis, inhibited the growth of these melanoma cells, both in vivo and in vitro by activating the $\mathrm{A}_{3} \mathrm{AR}$ (Yoshikawa et al., 2008).

In addition to melanoma cells, $\mathrm{A}_{3} \mathrm{ARs}$ are also expressed by the anti-tumor T-cells and possibly by NK cells (Gessi et al., 2004; Hoskin et al., 2008). A AR agonist activates NK cells in the mouse melanoma model, leading to the suppression of tumor growth and lung metastases (Harish et al., 2003). In a recent study, Morello et al. (2011) showed that $A_{3} A R$ agonist recruits NK cells to the tumor region to increase the killing of the tumor cells and reduce tumor growth.

The studies described in this section suggest an important anti-tumor action of $\mathrm{A}_{3} \mathrm{AR}$ agonists mediated via inhibition of the cyclic AMP-PKA pathway, which appears important for tumor growth. Additionally, due to the additive effects seen with other chemotherapeutic drugs, such as cyclophosphamide, the $\mathrm{A}_{3} \mathrm{AR}$ agonists can also be used as part of a combination therapy against melanoma. Importantly, these studies support an indirect role of $A_{3} A R$ in mediating its anti-tumor action, primarily via T lymphocytes and NK cells.

\section{2 $\mathrm{A}_{2 \mathrm{~A}}$ adenosine receptors and melanoma}

The $\mathrm{A}_{2 \mathrm{~A}} \mathrm{ARs}$ mediate anti-tumor action via a direct and an indirect pathway, the latter pathway involving immune cells. Expression of $\mathrm{A}_{2 \mathrm{~A}} \mathrm{ARs}$ in melanoma cell line A375 was 
first reported by Merighi et al (2001). These cells express $A_{2 A} A R$, as determined by RT-PCR and radioligand binding assays. Activation of $\mathrm{A}_{2 \mathrm{~A}} \mathrm{AR}$ on these melanoma cells increased cyclic AMP levels and led to death of melanoma cells (Merighi et al., 2002).

The $\mathrm{A}_{2 \mathrm{~A}} \mathrm{AR}$ could mount a significant anti-tumor action against melanoma through an indirect mechanism. $\mathrm{A}_{2 \mathrm{~A}} \mathrm{ARs}$ are expressed on $\mathrm{CD}^{+}$and $\mathrm{CD} 8^{+}$T-lymphocytes (Koshiba et al., 1999), the immune cells that infiltrate the tumor microenvironment as part of the antitumor defense mechanism (Shankaran et al., 2001). The importance of specific antimelanoma T-cells lies in the fact that the adoptive transfer of such cells in patients with metastatic melanoma resulted in the regression of the tumor at metastatic sites along with the mounting of an immune response against the melanoma cells (Dudley et al., 2002). Functionally, adenosine and $\mathrm{A}_{2 \mathrm{~A}} \mathrm{AR}$ specific agonists suppressed the activity of the antitumor T-cells (Butler et al., 2003; Zhang et al., 2004), leading to enhanced tumor growth. In fact, mice deficient in $\mathrm{A}_{2 \mathrm{~A}} \mathrm{AR}$ developed an autoimmune response against the immunogenic melanoma cells and complete tumor rejection in $\sim 60 \%$ of the mice (Ohta et al., 2006).

$\mathrm{A}_{2 \mathrm{~A}} \mathrm{ARs}$ have also been studied in lymphokine-activated killer (LAK) cells (Raskovalova et al., 2005). LAK cells are the NK cells that become activated by cytokines and demonstrate enhanced anti-tumor activity against cancer cells (Zamai et al., 2007). Although expression of $\mathrm{A}_{2 \mathrm{~A}} \mathrm{ARs}$ have not been well established in these cells, it has been shown that the LAK cells generated from $\mathrm{A}_{1} \mathrm{AR}$ - and $\mathrm{A}_{3} \mathrm{AR}$-deficient mice failed to show any inhibitory effects of adenosine. In contrast, $\mathrm{LAK}$ cells from $\mathrm{A}_{2 \mathrm{~A}} \mathrm{AR}$-deficient mice were resistant to adenosine response (Raskovalova et al., 2005).

The preceding discussion does not provide a clear outcome of the responses of adenosine via a direct and indirect pathway in vivo or in the clinical settings. However, the indirect pathway of $\mathrm{A}_{2 \mathrm{~A}} \mathrm{AR}$ action appears to be dominant since inhibition or knockout of these receptors enhanced tumor regression in vivo (Ohta et al., 2006, Raskovalova et al., 2007).

\section{3 $\mathrm{A}_{2 B}$ adenosine receptors and melanoma}

$A_{2 B} A R s$ are the low affinity adenosine receptors (Fredholm et al., 2001) which are overexpressed in various tumors (Panjehpour et al., 2005, Li et al., 2005, Phelps et al., 2006). These receptors are involved in promotion of the tumor growth (Ryzhov et al., 2008). $\mathrm{A}_{2 \mathrm{~B}} \mathrm{AR}$ has been characterized in A375 human malignant melanoma cells where its activation led to increases in cyclic AMP levels (Merighi et al., 2001).

As with the $\mathrm{A}_{2 \mathrm{~A}} \mathrm{ARs}, \mathrm{A}_{2 \mathrm{~B}} \mathrm{ARs}$ are also expressed by the normal as well as activated $\mathrm{T}$ lymphocytes (Mirabet et al., 1999). As mentioned above, these activated T-lymphocytes provide host defense response against the tumor cells. Similar to the $A_{2 A} A R$, the $A_{2 B} A R$ inhibits T-lymphocytes function and promotes tumor growth (Ohta et al., 2006). These investigators demonstrated that mice in which $A_{2 A} A R$ was deleted showed a $60 \%$ tumor regression, suggesting a tumor enhancing action of the $A_{2 B} A R$ (Ohta et al. (2006).

\section{4 $A_{1}$ adenosine receptors and melanoma}

One of the first studies of ARs in melanoma examined the role of $\mathrm{A}_{1} \mathrm{AR}$ on the motility of A2058 melanoma cells in vitro (Woodhouse et al., 1998). In this study, the authors showed that adenosine- and AMP-dependent chemotactic responses of melanoma cells were mediated via $A_{1} A R$ stimulation. This response was prevented by $A_{1} A R$ specific antagonist and also by pre-treatment with pertussis toxin, to uncouple the $A_{1} A R$ from its $G$ proteins. These data implicate the $\mathrm{A}_{1} \mathrm{AR}$ in chemotaxis of melanoma cells. The normal physiological 
extracellular concentrations of adenosine are low, ranging between 30-200 nM (Ballarín et al., 1991). However, there is a drastic increase in extracellular adenosine levels to micromolar levels under conditions of oxidative stress, such as hypoxia and ischemia (Rudolphi et al., 1992), as would be expected in the core of the solid tumors. Therefore, is highly likely that adenosine produced in the microenvironment of the melanoma could facilitate motility and metastasis. One potential target of $\mathrm{A}_{1} \mathrm{AR}$-mediated chemotaxis of melanoma cells is the central nervous system (Woodhouse et al., 1998). The melanoma cells have a high propensity for metastasizing to the brain. Malignant melanoma ranks as the fourth most common primary malignancy to metastasize to the brain (Wen et al., 2001), with almost 75\% prevalence rate determined at autopsies (Patel et al., 1978). One of the possible explanations for the increased brain metastases in melanoma could be increased adenosine levels in the brain produced by high rates of ATP consumption following neuronal activity (Woodhouse et al., 1998).

$\mathrm{A}_{1} \mathrm{AR}$ expression along with its biochemical and functional characterization has also been described in A375 human malignant melanoma cells (Merighi et al., 2001). It was shown that these cells express relatively low levels of $\mathrm{A}_{1} \mathrm{ARs}$ both at the transcript (as determine by low mRNA expression), and at the protein levels (as suggested by the low radioligand binding). These investigators observed no significant functional response of $A_{1} A R$ agonist on cyclic AMP levels in these cells (Merighi et al., 2001). Furthermore, $A_{1} A R$ antagonist failed to suppress the increased levels of IL-8 and VEGF induced by two chemotherapeutic drugs (Merighi et al., 2009). These studies suggest that the $A_{1} A R$ are expressed in melanoma cell lines used in vitro, which could account for the response to $A_{1} A R$ agonists. Whether the $\mathrm{A}_{1} \mathrm{AR}$ are expressed in melanoma tissues is not yet clear.

\section{Adenosine receptors signaling in melanoma}

The signaling mechanisms involved in the suppression or promotion of melanoma growth by adenosine receptors can be further sub-divided into direct (by acting on the melanoma cells), or indirect (by regulating the melanoma cell growth via immune cells).

\subsection{Direct signaling mechanisms}

Activation of the $\mathrm{A}_{3} \mathrm{AR}$ in melanoma has been shown to couple to activation of PLC leading (via $G_{q}$ ) to enhanced survival of A375 melanoma cells (Merighi et al., 2001). In contrast, activation of the $A_{3} A R$ negatively couples to adenylyl cyclase in melanoma cells which suppresses the Wnt signaling pathway. In these cells cyclic AMP, via PKA, increases glycogen synthase kinase (GSK)- $\beta$ and increased phosphorylation of $\beta$-catenin. This allow for enhanced transcription of genes, such as c-myc and cyclin D, which enhance tumor growth. As such, the $\mathrm{A}_{3} \mathrm{AR}$ suppress tumor growth by inhibiting adenylyl cyclase activity. Activation of the $A_{3} A R$ inhibits nuclear factor (NF)- $\mathrm{kB}$, which also negatively regulates tumor growth (Fishman et al., 2002; Fishman et al., 2004).

\subsection{Indirect signaling mechanisms}

As discussed above, the $\mathrm{A}_{2 \mathrm{~A}} \mathrm{AR}$ plays a critical role in tumor progression through their inhibitory action on anti-tumor immune cells, such as T-lymphocytes and LAK cells. This inhibition is exerted mainly by increasing the levels of cyclic AMP in these cells and activating PKA-dependent pathways. In a recently published study, anti-melanoma specific $\mathrm{CD}^{+}$and $\mathrm{CD}^{+}$T-cells activity was suppressed by adenosine and 2-chloroadenosine 
(Raskovalova et al., 2007). Furthermore, this inhibition was mimicked by $\mathrm{A}_{2 \mathrm{~A}} \mathrm{AR}$ specific agonist 2-p-(2-Carboxyethyl)phenethylamino-5'-N-ethylcarboxamidoadenosine hydrochloride hydrate (CGS21680), and was blocked by $\mathrm{A}_{2 \mathrm{~A}} \mathrm{AR}$ specific antagonist, 4-(-2-[7-amino-2-\{2furyl $\left\{\{1,2,4\}\right.$ triazolo $\{2,3-a\} \quad\{1,3,5\}$ triazin-5-yl-amino]ethyl)phenol (ZM241385). The $\mathrm{A}_{2 \mathrm{~A}} \mathrm{AR}-$ dependent effect was mediated by the cyclic AMP/PKA pathway. A $2 A$ AR activation increased cyclic AMP levels, which activate PKA and regulate different cellular function by phosphorylation of cellular targets. PKA consists of two regulatory and two catalytic subunits (Francis \& Corbin, 1999). Furthermore, two isoforms of PKA are known, PKA-I and PKA-II (Chin et al., 2002). In particular, activation of the PKA-I regulatory subunit was responsible for the T-cell suppressive effects of adenosine, as blockade of catalytic subunits of PKA was not able to reduce the adenosine effects while the PKA-I blocker efficiently suppressed the adenosine response (Raskovalova et al., 2007). The inhibitory effects of adenosine and its analogues reduced cytotoxicity of anti-melanoma specific T-cells and reduced production of cytokines, such as IFN- $\gamma$, IL-2 and TNF- $\alpha$ (Raskovalova et al., 2007). IFN- $\gamma$ is one of the critical cytokines involved in the anti-tumor action of the T-cells, as it inhibits the process of angiogenesis (Qin and Blankenstein, 2000). Thus, $A_{2 A} A R$ inhibition could be used in combination with the anti-angiogenic therapy. In this situation, $\mathrm{A}_{2 \mathrm{~A}} \mathrm{AR}$ inhibitors will enhance the immune response against the tumor cells and increase IFN- $\gamma$ secretion, leading to tumor cell killing and decreased angiogenesis.

Similar to the anti-tumor T-cell inhibition, adenosine and $\mathrm{A}_{2 \mathrm{~A}} \mathrm{AR}$-specific agonists also reduce the LAK cells-mediated anti-tumor response via cyclic AMP-PKA signaling (Lokshin et al., 2006). In addition to the involvement of the regulatory subunit of the PKA, PKA-I, the $\mathrm{A}_{2 \mathrm{~A}} \mathrm{AR}$-dependent response also exhibits complimentary inhibitory effect on LAK cells along with prostaglandin E2 (PGE2) (Lokshin et al., 2006; Su et al., 2008). The co-operative response of adenosine and PGE2 involves amplification of the cyclic AMP-PKA signaling, in addition to the increased CREB phosphorylation and inhibition of Akt (Su et al., 2008). This co-operative response of adenosine and PGE2 also leads to the activation of Csk, an inhibitor of the T-cell receptor (TCR) signaling (Su et al., 2011). Activated Csk in turn inhibits Lck, ZAP-70 and phosphorylated Akt. The interesting aspect of this co-operative action of adenosine and PGE2 is that pre-treatment with sub-suppressive doses of adenosine or PGE2 results in lack of inhibition of the tumor infiltrating lymphocytes (TILs). This effect is explained due to cross desensitization of the PGE2 and ARs. This process gives a new direction for the use of adoptive immunotherapy against the tumor cells. It is possible to improve the effectiveness of the anti-tumor immune cells by pre-treating them with low doses of PGE2 or $\mathrm{A}_{2 \mathrm{~A}} \mathrm{AR}$ agonist before their adoptive transfer (Su et al., 2011).

In contrast to the above mentioned mechanisms of $A_{2 A} A R$ in regulating the immune cells in the tumor microenvironment, an additional concept has been put forward that describes the role of $\mathrm{A}_{2 \mathrm{~A}} \mathrm{ARs}$ in suppressing the activation-induced cell death (AICD) of the $\mathrm{CD}^{+} \mathrm{T}$ cells (Himer et al., 2010). AICD is a phenomenon that results from TCR-mediated stimulation of the already activated T-cells, resulting in apoptosis. This action involves the interaction of Fas and Fas ligand (Green et al., 2003). Activation of $\mathrm{A}_{2 \mathrm{~A}} \mathrm{AR}$ by specific agonist reduced the expression of Fas and Fas ligand and prevented the killing of CD4+ cells by AICD. This process was PKA-dependent and it also involved the suppression of various transcription factors, such as NF-KB, nuclear factor of activated T cells (NF-AT) and early growth response (Egr)-1 and Egr-3 proteins (Himer et al., 2010). This anti-apoptotic response of $\mathrm{A}_{2 \mathrm{~A}} \mathrm{AR}$ on $\mathrm{CD}^{+} \mathrm{T}$ cells could promote a prolonged immune response by these cells. This action contrasts the inhibitory actions of $\mathrm{A}_{2 \mathrm{~A}} \mathrm{AR}$ on T-lymphocytes and LAK cells, which 
reduces their anti-tumor immune response. Although, this anti-AICD process has not been described in connection to the tumor cells, it will be interesting to determine if this is also true in the anti-tumor immune cells.

Although, $A_{2 A}$ and $A_{2 B}$ ARs have been primarily studied in context to anti-tumor immune cells functions, immune cells also express $A_{3} A R s$ (Hoskin et al., 2008). However, in contrast to the $A_{2 A}$ and $A_{2 B} A R$, activation of $A_{3} A R$ boost the anti-tumor immune response (Harish et al., 2003; Morello et al., 2011). Treatment with $A_{3} A R$ agonist in the murine B16-F10 melanoma model resulted in an increased infiltration and activation of the NK and CD8 $8^{+} \mathrm{T}$ cells in the melanoma tissues which was associated with increased levels of IL-12. Furthermore, transfer of splenocytes from the $\mathrm{A}_{3} \mathrm{AR}$ agonist-treated mice suppressed metastasis to the lungs of recipient mice (Harish et al., 2003). In contrast, treatment of nude mice with $\mathrm{A}_{3} \mathrm{AR}$ agonist failed to have any effect on the melanoma growth (Morello et al., 2011). This effect of $A_{3} A R$ agonist on NK and T-cells was associated with increased TNF- $\alpha$ and IFN- $\gamma$ levels in the melanoma tissues, suggestive of heightened immune response against the tumor cells (Morello et al., 2011). Thus, the use of $\mathrm{A}_{3} \mathrm{AR}$ agonists can provide strong anti-tumor actions on melanoma cells by a direct inhibitory effects on the tumor cells and indirectly via activation of the immune system.

\section{Reactive oxygen species and melanoma}

A number of studies support a role of reactive oxygen species (ROS) in the proliferation and metastasis of melanoma cells. For example, ROS can select for chemoresistance by increasing the expression of glutathione, an antioxidant. ROS can promote cell survival through activation of NF- $\mathrm{KB}$ and MAPK pathways and inhibition of p53. ROS can also promote melanoma metastasis. High ROS levels in the tumor microenvironment is important for killing melanoma cells that are susceptible to ROS and for "selecting" those cells which are resistant. These resistant cells are endowed with higher levels of glutathione. High ROS levels can induce DNA mitochondrial damage in melanoma cells which can facilitate the invasive and metastatic process (Poetsch et al., 2004). In addition high levels of ROS can induce epigenetic changes through stimulating DNA methylation (Campos et al., 2007), which also can promote invasiveness (Seftor et al., 2005). ROS can also contribute to increased melanoma cell proliferation by activating redox-sensitive transcription factors, such as NF- $\kappa B$, activator protein-1 (AP-1) and c-myc (Karin et al., 2001). High ROS levels could also increase killing of normal cells in the tumor microenvironment (such as vascular endothelial cells) and promote extravasation and metastasis (Offner et al., 1992, 1996). ROS could also induce expression of cell adhesion molecules on the primary tumor cells and endothelial cells which could promote the metastatic process. In support of these findings, a number of in vivo studies in experimental animals demonstrated that antioxidants/antioxidant enzymes were effective in lowering the metastatic potential of melanoma cells (for review, see Joosse et al., 2010). However, all antioxidants/antioxidant enzymes were not effective. While catalase and superoxide dismutase clearly demonstrated antitumor actions, glutathione appeared to increase metastasis (Joosse et al., 2010).

However, ROS has also been linked to the antitumor action of drugs against metastatic melanoma. The effectiveness of the agent elesclomol against melanoma has been attributed to its ability to promote intracellular ROS generation. When used in association with paclitaxel in a Phase 2 clinical trial, elesclomol increased the progression-free survival of patients to 3.7 months versus 1.8 months for the second group of patients treated with paclitaxel alone (Fruehauf and Trapp, 2008). 


\subsection{NADPH oxidase: source of ROS in melanoma}

The nicotinamide adenine dinucleotide phosphate (NADPH) oxidase system is a superoxide producing enzyme complex that has historically been studied in the phagocytes as the source of respiratory burst against the ingested microbes. However, this enzyme system is also found in other tissues including many cancer tissues and cells. NADPH oxidase complex consists of different subunits of which gp91phox, p47phox, p67phox and p22phox are required for the activity of the enzyme system. The p40phox and small GTP-binding proteins, Rac1 and Rap1A, form the holoenzyme component that promote enzyme activity and ROS generation (Lassègue \& Clempus, 2003).

Melanoma cell lines express high levels of p22phox, gp91phox, NOX4 (a homolog of gp91phox) and p67phox subunits, with relatively lower expression of p47phox subunit (Brar et al., 2002). Over expression of these subunits in M1619 melanoma cells is associated with increased activity of NADPH oxidase and high ROS generation, which in turn leads to high rates of cell proliferation. This process is dependent on the cyclic AMP responsive element (CRE), as inhibition of NADPH oxidase suppressed the cell growth as well as CRE-binding activity (Brar et al., 2002).

Both gp91phox and its homolog NOX4 are expressed in melanoma cells and appear to mediate differential effects on these cells. NOX4 appears to be critical for the melanoma growth. This observation is supported by the following observations. First, increased NOX4 expression is observed in human melanoma tissues and cell lines. Second, suppression of melanoma tumor growth in nude mice could be produced by silencing the NOX4 expression. Third, inhibition of melanoma cell proliferation and $\mathrm{G}_{2}-\mathrm{M}$ cell cycle transition in cultures is produced by small interfering (si) RNA against NOX4 (Yamaura et al., 2009). However, gp91phox subunit might play an important role in the invasiveness and metastasis of melanoma cells. The primary melanoma tumors were not different in the gp91 knockout mice, compared to wild type, but they showed reduced invasion and lung metastases. Additionally, when gp91phox knockout mice were injected with the phagocytes from wild type mice, they showed increased in metastatic ability (Okada et al., 2006).

In addition to the role of NOX isoforms discussed in the previous paragraph, two other subunits of NADPH oxidase, Rac1 and p47phox, also play important roles in ROS generation, proliferation and motility of the melanoma cells. Rac1 is a small GTP-binding protein that is involved in cell motility and ROS generation as a component of the NADPH oxidase system (Hall, 1992; Lassègue \& Clempus, 2003 ). In B16F10 melanoma cells, hyaluronidase increased ROS generation and cell motility in Rac1-dependent fashion. Furthermore, Rac1 is also involved in the membrane translocation and activation of p47phox subunit. Inhibition of Rac1 activity by a dominant-negative Rac1 (Rac1N17) and by siRNA again p47phox reduced the ROS generation by hyaluronidase and the cell migration ability of these cells (Kim et al., 2008). In addition to stimulating proliferation and motility, both Rac1 and p47phox can also regulate differentiation of the melanoma cells. The NADPH oxidase inhibitor, diphenylene iodonium, changed the morphology of the melanoma cells, increased the production of melanin pigment and also increased the expression of a pro-melanocyte differentiation factor microphthalmia-associated transcription factor (MITF). Expression of MITF was also increased by suppressing the expression of Rac1 and p47phox by their respective siRNAs (Zhao et al., 2008). Hence, targeting the NADPH oxidase system to reduce the high ROS levels in melanoma cells could provide an effective therapeutic strategy to suppress the growth, migration and metastasis of the melanoma cells. 


\section{2 $A_{3} A R$ inhibits NADPH oxidase}

As discussed above, the $\mathrm{A}_{3} \mathrm{AR}$ mediates both direct and indirect inhibition of melanoma cell growth (see section 4.1 and 4.2). In a recently published study, we showed that one of the potential targets for $\mathrm{A}_{3} \mathrm{AR}$ is the NADPH oxidase ROS generating system (Jajoo et al., 2009). In this study $\mathrm{A}_{3} \mathrm{AR}$ agonist decreased the NADPH oxidase-dependent high ROS generation in prostate cancer cells, resulting in inhibition of tumor growth and metastasis (Jajoo et al., 2009). Although this study was performed in androgen-resistant prostate cancer cells, these findings could be applied to the melanoma cells due to inherent similarities with the prostate cancer cells at the biochemical and molecular level. First, melanoma cells generate high ROS mediated by the NADPH oxidase system. Further, high ROS levels are responsible for the tumor cell growth, migration and invasiveness (Brar et al, 2002; Kim et al., 2008; Yamaura et al., 2009). Second, $A_{3} A R$ expression is well characterized in melanoma cells along with the anti-tumor effects of the $\mathrm{A}_{3} \mathrm{AR}$ agonists (Merighi et al., 2001; Fishman et al., 2002). Third, similar to our findings in prostate cancer cells, melanoma cells also exhibit higher levels of cyclic AMP resulting in increased activation of PKA and its downstream signaling pathways. Furthermore, $\mathrm{A}_{3} \mathrm{AR}$ activation in both types of tumor cells exerted its effect by regulating the Wnt signaling pathways (Fishman et al., 2002; 2003). Fourth, we found increased ERK1/2-MAP kinase activation in the prostate cancer cells, which was reduced by $A_{3} A R$ agonist (Jajoo et al., 2009). In melanoma, $A_{3} A R$ activation reduced the pERK1/2 levels and the ERK1/2-MAP kinase pathway (Merighi et al., 2005). As such, we propose that inhibition of NADPH oxidase system resulting in reduced levels of ROS generation can also account for $\mathrm{A}_{3} \mathrm{AR}$ mediated anti-melanoma effects.

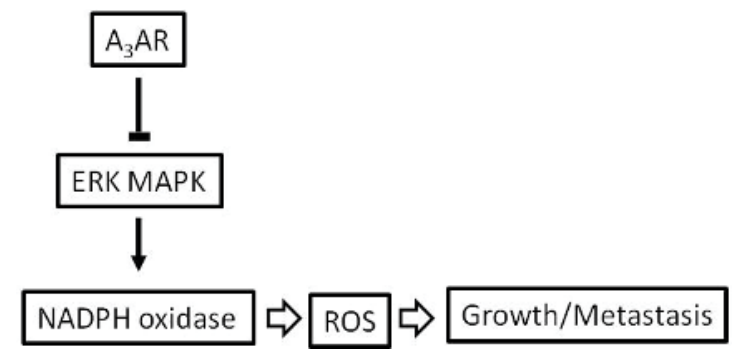

Fig. 2. Proposed mechanism of inhibition of the growth and metastasis of melanoma cells by $\mathrm{A}_{3} \mathrm{AR}$ agonists. Activation of the $\mathrm{A}_{3} \mathrm{AR}$ is expected to inhibit ERK MAPK activity by inhibiting an upstream cyclic AMP-PKA pathway. Inhibition of ERK reduces activation of NADPH oxidase, thereby reducing ROS production. ROS contributes significantly to the growth and metastasis of melanoma cells

\section{Conclusion}

Adenosine plays an important role in modulating the progression of melanoma. Several AR types present on these cells would determine whether endogenously released adenosine promote or inhibit tumor growth and metastasis. In general, agonists of the $A_{2 A}$ and $A_{2 B} A R s$ are expected to promote the growth and metastasis of melanoma by inhibiting an indirect pathway which involves T-lymphocytes and NK cells-promoted killing of melanoma cells. As such, antagonists of these receptors should increase activity of these immune cells and promote anti-tumor actions. On the other hand, agonists of the $A_{3} A R$ are expected to 
provide anti-tumor action by activating these receptors directly on melanoma cells to reduce proliferation and metastasis. In addition, activation of the $\mathrm{A}_{3} \mathrm{AR}$ is expected to provide antitumor actions indirectly by activating T-lymphocytes and NK cells to promote tumor cell destruction. Therefore, antagonists of the $A_{2 A}$ and $A_{2 B} A R$ and agonists of the $A_{3} A R$ should be considered as potential treatments for melanoma. These drugs could be combined with standard treatment regimen to enhance treatment efficacy.

\section{Acknowledgement}

The authors are funded by grants R15-CA135494, RO1-DC 002396 and F32DC009950 from the National Institute of Health and an Excellence in Academic Medicine Award from SIU School of Medicine.

\section{References}

Adair, T.H. (2005). Growth regulation of the vascular system: an emerging role for adenosine. Am J Physiol Regul Integr Comp Physiol, Vol. 289, No. 2, pp. R283-R296.

Arslan, G. \& Fredholm, B.B. (2000). Stimulatory and inhibitory effects of adenosine A(2A) receptors on nerve growth factor-induced phosphorylation of extracellular regulated kinases 1/2 in PC12 cells. Neurosci Lett, Vol. 292, No. 3, pp. 183-186.

Atallah, E. \& Flaherty, L. (2005). Treatment of metastatic malignant melanoma. Curr Treat Options Oncol, Vol. 6, No. 3, pp. 185-193.

Balch, C.M.; Reintgen, D.S.; Kirkwood, J.M.; Houghton, A.; Peters, L. \& Ang, K.K. (1997). Cutaneous Melanoma. Cancer: Principles and Practice of Oncology (5th Ed.), Lippincott-Raven, Philadelphia.

Baldwin, S.A.; Beal, P.R.; Yao, S.Y.; King, A.E.; Cass, C.E. \& Young, J.D. (2004). The equilibrative nucleoside transporter family, SLC29. Pflugers Arch, Vol. 447, No. 5, pp. 735-743.

Ballarín, M.; Fredholm, B.B.; Ambrosio, S. \& Mahy, N. (1991). Extracellular levels of adenosine and its metabolites in the striatum of awake rats: inhibition of uptake and metabolism. Acta Physiol Scand, Vol. 142, No. 1, pp. 97-103.

Bar-Yehuda, S.; Barer, F.; Volfsson, L. \& Fishman, P. (2001). Resistance of muscle to tumor metastases: a role for a3 adenosine receptor agonists. Neoplasia, Vol. 3, No. 2, pp. 125-131.

Berne, R.M.; Knabb, R.M.; Ely, S.W. \& Rubio, R. (1983). Adenosine in the local regulation of blood flow: a brief overview. Fed Proc, Vol. 42, No. 15, pp. 3136-3142.

Blay, J.; White, T.D. \& Hoskin, D.W. (1997). The extracellular fluid of solid carcinomas contains immunosuppressive concentrations of adenosine. Cancer Res, Vol. 57, No. 13, pp. 2602-2605.

Braun, N.; Lenz, C.; Gillardon, F.; Zimmermann, M. \& Zimmermann, H. (1997). Focal cerebral ischemia enhances glial expression of ecto-5'-nucleotidase. Brain Res, Vol. 766, No. 1-2, pp. 213-226.

Brar, S.S.; Kennedy, T.P.; Sturrock, A.B.; Huecksteadt, T.P.; Quinn, M.T.; Whorton, A.R. \& Hoidal, J.R. (2002). An NAD(P)H oxidase regulates growth and transcription in melanoma cells. Am J Physiol Cell Physiol, Vol. 282, No. 6, pp. C1212-C1224.

Brown, J.R.; Cornell, K. \& Cook, P.W. (2000). Adenosine- and adenine-nucleotide-mediated inhibition of normal and transformed keratinocyte proliferation is dependent upon 
dipyridamole-sensitive adenosine transport. J Invest Dermatol, Vol. 115, No. 5, pp. 849-859.

Butler, J.J.; Mader, J.S.; Watson, C.L.; Zhang, H.; Blay, J. \& Hoskin, D.W. (2003). Adenosine inhibits activation-induced $\mathrm{T}$ cell expression of CD2 and CD28 co-stimulatory molecules: role of interleukin-2 and cyclic AMP signaling pathways. J Cell Biochem, Vol. 89, No. 5, pp. 975-991.

Campos, A.C.; Molognoni, F.; Melo, F.H.; Galdieri, L.C.; Carneiro, C.R.; D'Almeida, V.; Correa, M. \& Jasiulionis, M.G. (2007). Oxidative stress modulates DNA methylation during melanocyte anchorage blockade associated with malignant transformation. Neoplasia, Vol. 9, No. 12, pp. 1111-1121.

Chaudary, N.; Naydenova, Z.; Shuralyova, I. \& Coe, I.R. (2004). Hypoxia regulates the adenosine transporter, mENT1, in the murine cardiomyocyte cell line, HL-1. Cardiovasc Res, Vol. 61, No. 4, pp. 780-788.

Chin, K.V.; Yang, W.L.; Ravatn, R.; Kita, T.; Reitman, E.; Vettori, D.; Cvijic, M.E.; Shin, M. \& Iacono, L. (2002). Reinventing the wheel of cyclic AMP: novel mechanisms of cAMP signaling. Ann N Y Acad Sci, Vol. 968, pp. 49-64.

De Plaen, E.; Arden, K.; Traversari, C.; Gaforio, J.J.; Szikora, J.P.; De Smet, C.; Brasseur, F.; van der Bruggen, P.; Lethé, B.; Lurquin, C.; et al. (1994). Structure, chromosomal localization, and expression of 12 genes of the MAGE family. Immunogenetics, Vol. 40, No. 5, pp. 360-369.

Dickenson, J.M.; Blank, J.L. \& Hill, S.J. (1998). Human adenosine A1 receptor and P2Y2purinoceptor-mediated activation of the mitogen-activated protein kinase cascade in transfected CHO cells. Br J Pharmacol, Vol. 124, No. 7, pp. 1491-1499.

Drury, A.N. \& Szent-Gyorgyi, A. (1929). The physiological activity of adenine compounds with especial reference to their action upon the mammalian heart. J Physiol, Vol. 68, No. 3, pp. 213-237.

Dudley, M.E.; Wunderlich, J.R.; Robbins, P.F.; Yang, J.C.; Hwu, P.; Schwartzentruber, D.J.; Topalian, S.L.; Sherry, R.; Restifo, N.P.; Hubicki, A.M.; Robinson, M.R.; Raffeld M.; Duray, P.; Seipp, C.A.; Rogers-Freezer, L.; Morton, K.E.; Mavroukakis, S.A.; White, D.E. \& Rosenberg, S.A. (2002). Cancer regression and autoimmunity in patients after clonal re-population with antitumor lymphocytes. Science, Vol. 298, No. 5594, pp. 850-854.

Eltzschig, H.K.; Abdulla. P.; Hoffman, E.; Hamilton, K.E.; Daniels, D.; Schonfeld, C.; Löffler, M.; Reyes, G.; Duszenko, M.; Karhausen, J.; Robinson, A.; Westerman, K.A.; Coe, I.R. \& Colgan, S.P. (2005). HIF-1-dependent repression of equilibrative nucleoside transporter (ENT) in hypoxia. J Exp Med, Vol. 202, No. 11, pp. 1493-1505.

Etique, N., Grillier-Vuissoz, I., Lecomte, J., \& Flament, S. (2009) Crosstalk between adenosine receptor $\left(\mathrm{A}_{2 \mathrm{~A}}\right.$ isoform) and ERalpha mediates ethanol action in MCF-7 breast cancer cells. Oncol Rep, Vol. 21, No. 4, pp. 977-981.

Fang,Y. \& Olah, M.E. (2007). Cyclic AMP-dependent, protein kinase A-independent activation of extracellular signal-regulated kinase $1 / 2$ following adenosine receptor stimulation in human umbilical vein endothelial cells: role of exchange protein activated by cAMP 1 (Epac1). J Pharmacol Exp Ther, Vol. 322, No. 3, pp. 1189-2000.

Faure, M.; Voyno-Yasenetskaya, T.A. \& Bourne, H.R. (1994). cAMP and beta gamma subunits of heterotrimeric $G$ proteins stimulate the mitogen-activated protein kinase pathway in COS-7 cells. J Biol Chem, Vol. 269, No. 11, pp. 7851-7854. 
Feoktistov, I. \& Biaggioni, I. (1997). Adenosine A2B receptors. Pharmacol Rev, Vol. 49, No. 4, pp. 381-402.

Fishman, P.; Bar-Yehuda, S.; Barer, F.; Madi, L.; Multani, A.S. \& Pathak, S. (2001). The A3 adenosine receptor as a new target for cancer therapy and chemoprotection. Exp Cell Res, Vol. 269, No. 2, pp. 230-236.

Fishman, P.; Madi, L.; Bar-Yehuda, S.; Barer, F.; Del Valle, L. \& Khalili, K. (2002). Evidence for involvement of Wnt signaling pathway in IB-MECA mediated suppression of melanoma cells. Oncogene, Vol. 21, No. 25, pp. 4060-4064.

Fishman, P.; Bar-Yehuda, S.; Ohana, G.; Barer, F.; Ochaion, A.; Erlanger, A. \& Madi, L. (2004) An agonist to the A3 adenosine receptor inhibits colon carcinoma growth in mice via modulation of GSK-3 $\beta$ and NF-kB. Oncogene, Vol. 23, No. 14, pp. 2465-2471.

Fishman, P.; Bar-Yehuda, S.; Ardon, E.; Rath-Wolfson, L.; Barrer, F.; Ochaion, A. \& Madi, L. (2003). Targeting the $\mathrm{A}_{3}$ adenosine receptor for cancer therapy: inhibition of prostate carcinoma cell growth by $\mathrm{A}_{3} \mathrm{AR}$ agonist. Anticancer Res, Vol. 23, No. 3A, pp. 2077-2083.

Francis, S.H. \& Corbin, J.D. (1999). Cyclic nucleotide-dependent protein kinases: intracellular receptors for cAMP and cGMP action. Crit Rev Clin Lab Sci, Vol. 36, No. 4, pp. 275-328.

Fredholm, B.B.; AP, I.J.; Jacobson, K.A.; Klotz, K.N. \& Linden, J. (2001). International Union of Pharmacology. XXV. Nomenclature and classification of adenosine receptors. Pharmacol Rev, Vol. 53, No. 4, pp. 527-552.

Fredholm, B.B.; IJzerman, A.P.; Jacobson, K.A.; Klotz, K.N. \& Linden, J. (2001). International Union of Pharmacology. XXV. Nomenclature and classification of adenosine receptors. Pharmacol Rev, Vol. 53, No. 4, pp. 527-552.

Fruehauf, J.P. \& Trapp, V. (2008). Reactive oxygen species: an Achilles' heel of melanoma? Expert Rev Anticancer Ther, Vol. 8, No. 11, pp. 1751-1757.

Gao, Z.; Li, B.S.; Day, Y.J. \& Linden, J. (2001). A 3 adenosine receptor activation triggers phosphorylation of protein kinase $\mathrm{B}$ and protects rat basophilic leukemia $2 \mathrm{H} 3$ mast cells from apoptosis. Mol Pharmacol, Vol. 59, No. 1, pp. 76-82.

Gessi, S.; Varani, K.; Merighi, S.; Cattabriga, E.; Avitabile, A.; Gavioli, R.; Fortini, C.; Leung, E.; Mac Lennan, S. \& Borea, P.A. (2004). Expression of A3 adenosine receptors in human lymphocytes: up-regulation in T cell activation. Mol Pharmacol, Vol. 65, No. 3, pp. 711-719.

Grant, M.B.; Tarnuzzer, R.W.; Caballero, S.; Ozeck, M.J.; Davis, M.I.; Spoerri, P.E.; Feoktistov, I.; Biaggioni, I.; Shryock, J.C. \& Belardinelli L. (1999) Adenosine receptor activation induces vascular endothelial growth factor in human retinal endothelial cells. Circ Res, Vol. 85, No. 8, pp. 699-706.

Green, D.R.; Droin, N. \& Pinkoski, M. (2003). Activation-induced cell death in T cells. Immunol Rev, Vol. 193, pp. 70-81.

Gorlach, A. (2005). Control of adenosine transport by hypoxia. Circ Res, Vol. 97, No. 1, pp. 13.

Gupta, K. \& Zhang, J. (2005). Angiogenesis: a curse or cure? Postgrad Med J, Vol. 81, No. 954, pp. 236-242.

Hall, A. (1992). Ras-related GTPases and the cytoskeleton. Mol Biol Cell, Vol. 3, No. 5, pp. 475-479. 
Harish, A.; Hohana, G.; Fishman, P.; Arnon, O. \& Bar-Yehuda, S. (2003). A 3 adenosine receptor agonist potentiates natural killer cell activity. Int J Oncol, Vol. 23, No. 4, pp. 1245-1249.

Harpio, R. \& Einarsson, R. (2004). S100 proteins as cancer biomarkers with focus on S100B in malignant melanoma. Clin Biochem, Vol. 37, No. 7, pp. 512-518.

Hart, M.L.; Grenz, A.; Gorzolla, I.C.; Schittenhelm, J.; Dalton, J.H., \& Eltzschig, H.K. (2011) Hypoxia-inducible factor-1 $\alpha$-dependent protection from intestinal ischemia/reperfusion injury involves ecto-5'-nucleotidase (CD73) and the $A_{2 B}$ adenosine receptor. J Immunol, Vol. 186, No.7, pp. 4367-4374.

St Hilaire, C.; Koupenova, M.; Carroll, S.H.; Smith, B.D., \& Ravid, K. (2008)TNF- $\alpha$ upregulates the $\mathrm{A}_{2 \mathrm{~B}}$ adenosine receptor gene: The role of $\mathrm{NAD}(\mathrm{P}) \mathrm{H}$ oxidase 4. Biochem Biophys Res Commun, Vol. 375, No. 3, pp. 292-296.

Himer, L.; Csóka, B.; Selmeczy, Z.; Koscsó, B.; Pócza, T.; Pacher, P.; Németh, Z.H.; Deitch, E.A.; Vizi, E.S.; Cronstein, B.N. \& Haskó, G. (2010). Adenosine A2A receptor activation protects $\mathrm{CD} 4+\mathrm{T}$ lymphocytes against activation-induced cell death. FASEB J, Vol. 24, No. 8, pp. 2631-2640.

Hoskin, D.W.; Mader, J.S.; Furlong, S.J.; Conrad, D.M. \& Blay, J. (2008) Inhibition of T cell and natural killer cell function by adenosine and its contribution to immune evasion by tumor cells (Review). Int J Oncol, Vol. 32, No. 3, pp. 527-535.

Jacobson, K.A. Gao, Z.G. (2006). Adenosine receptors as therapeutic targets. Nat Rev Drug Discov, Vol. 5, No. 3, pp. 247-264.

Jajoo, S.; Mukherjea, D.; Watabe, K. \& Ramkumar, V. (2009). Adenosine A3 receptor suppresses prostate cancer metastasis by inhibiting NADPH oxidase activity. Neoplasia, Vol. 11 No. 11, pp. 1132-1145.

Joosse, A.; De Vries, E.; van Eijck, C.H.; Eggermont, A.M.; Nijsten, T. \& Coebergh, J.W. (2010). Reactive oxygen species and melanoma: an explanation for gender differences in survival? Pigment Cell Melanoma Res, Vol. 23, No. 3, pp. 352-364.

Karin, M.; Takahashi, T.; Kapahi, P.; Delhase, M.; Chen, Y.; Makris, C.; Rothwarf, D.; Baud, V.; Natoli, G.; Guido, F. \& Li, N. (2001). Oxidative stress and gene expression: the AP-1 and NF-kappaB connections. Biofactors, Vol. 15, Vol. 2-4, pp. 87-89.

Kawakami, Y. \& Rosenberg, S.A. (1996). T-cell recognition of self peptides as tumor rejection antigens. Immunol Res, Vol. 15, No. 3, pp. 179-180.

Kim, Y.; Lee, Y.S.; Choe, J.; Lee, H.; Kim, Y.M. \& Jeoung D. (2008). CD44-epidermal growth factor receptor interaction mediates hyaluronic acid-promoted cell motility by activating protein kinase $\mathrm{C}$ signaling involving Akt, Rac1, Phox, reactive oxygen species, focal adhesion kinase, and MMP-2. J Biol Chem, Vol. 283, No. 33, pp. 2251322528.

Khoa, N.D.; Montesinos, M.C.; Reiss, A.B.; Delano, D.; Awadallah, N. \& Cronstein, B.N. (2001) Inflammatory cytokines regulate function and expression of adenosine A(2A) receptors in human monocytic THP-1 cells. J Immunol, Vol. 167, No. 7, pp. 4026-4032.

Koshiba, M.; Rosin, D.L.; Hayashi, N.; Linden, J. \& Sitkovsky, M.V. (1999). Patterns of A2A extracellular adenosine receptor expression in different functional subsets of human peripheral $\mathrm{T}$ cells: flow cytometry studies with anti-A2A receptor monoclonal antibodies. Mol Pharmacol, Vol. 55, No. 3, pp. 614-624. 
Lassègue, B. \& Clempus, R.E. (2003). Vascular NAD $(\mathrm{P}) \mathrm{H}$ oxidases: specific features, expression, and regulation. Am J Physiol Regul Integr Comp Physiol, Vol. 285, No. 2, pp. R277-R297.

Lee, J.A. (1982). Melanoma and exposure to sunlight. Epidemol Rev, Vol. 4, pp. 110-106.

Lee, J.A. \& Scotto, J. (1993). Melanoma: linked temporal and latitude changes in the United States. Cancer Causes Control, Vol. 4, No. 5, pp. 413-418.

Li, S.; Huang, S. \& Peng, S.B. (2005). Overexpression of G protein-coupled receptors in cancer cells: involvement in tumor progression. Int J Oncol, Vol. 27, No. 5, pp. 13291339.

Linden, J. (1991) Structure and function of A1 adenosine receptor. FASEB J, Vol. 5, No. 12, pp. 2668-2676.

Lokshin, A.; Raskovalova, T.; Huang, X.; Zacharia, L.C.; Jackson, E.K. \& Gorelik, E. (2006). Adenosine-mediated inhibition of the cytotoxic activity and cytokine production by activated natural killer cells. Cancer Res, Vol. 66, No. 15, pp. 7758-7765.

Madi, L.; Bar-Yehuda, S.; Barer, F.; Ardon, E.; Ochaion, A. \& Fishman, P. (2003). A 3 adenosine receptor activation in melanoma cells: association between receptor fate and tumor growth inhibition. J Biol Chem, Vol. 278, No. 43, pp. 42121-42130.

Madi, L.; Ochaion, A.; Rath-Wolfson, L.; Bar-Yehuda, S.; Erlanger, A.; Ohana, G.; Harish, A.; Merimski, O.; Barer, F. \& Fishman, P. (2004). The $\mathrm{A}_{3}$ adenosine receptor is highly expressed in tumor versus normal cells: potential target for tumor growth inhibition. Clin Cancer Res, Vol. 10, No. 13, pp. 4472-4479.

Marchand, M.; Brasseur, F.; van der Bruggen, P.; Coulie, P. \& Boon, T. (1993). A gene encoding an antigen recognized by cytolytic T lymphocytes on a human melanoma. Dermatology, Vol. 186, No. 4, pp. 278-280.

Merighi, S.; Varani, K.; Gessi, S.; Cattabriga, E.; Iannotta, V.; Ulouglu, C.; Leung, E. \& Borea, P.A. (2001). Pharmacological and biochemical characterization of adenosine receptors in the human malignant melanoma A375 cell line. Br J Pharmacol, Vol. 134, No. 6, pp. 1215-1226.

Merighi, S.; Mirandola, P.; Milani, D.; Varani, K.; Gessi, S.; Klotz, K.N.; Leung, E.; Baraldi, P.G. \& Borea, P.A. (2002). Adenosine receptors as mediators of both cell proliferation and cell death of cultured human melanoma cells. J Invest Dermatol, Vol. 119, No. 4, pp. 923-933.

Merighi, S.; Benini, A.; Mirandola, P.; Gessi, S.; Varani, K.; Leung, E.; Maclennan, S. \& Borea, P.A. (2005). A3 adenosine receptor activation inhibits cell proliferation via phosphatidylinositol 3-kinase/ Akt-dependent inhibition of the extracellular signalregulated kinase 1/2 phosphorylation in A375 human melanoma cells. J Biol Chem, Vol. 280, No. 20, pp. 19516-19526.

Merighi, S.; Benini, A.; Mirandola, P.; Gessi, S.; Varani, K.; Leung, E.; Maclennan, S. \& Borea, P.A. (2006). Adenosine modulates vascular endothelial growth factor expression via hypoxia-inducible factor-1 in human glioblastoma cells. Biochem Pharmacol, Vol. 72, No. 1, pp. (19-31).

Merighi, S.; Simioni, C.; Gessi, S.; Varani, K.; Mirandola, P.; Tabrizi, M.A.; Baraldi, P.G. \& Borea, P.A. (2009). A(2B) and $\mathrm{A}(3)$ adenosine receptors modulate vascular endothelial growth factor and interleukin-8 expression in human melanoma cells treated with etoposide and doxorubicin. Neoplasia, Vol. 10, No. 10, pp. 1064-1073. 
Mirabet, M.; Herrera, C.; Cordero, O.J.; Mallol, J.; Lluis, C. \& Franco, R. (1999). Expression of $\mathrm{A} 2 \mathrm{~B}$ adenosine receptors in human lymphocytes. Their role in $\mathrm{T}$ cell activation. J Cell Sci, Vol. 112, Pt. 4, pp. 491-502.

Mirza, A.; Basso, A.; Black, S.; Malkowski, M.; Kwee, L.; Pachter, J.A.; Lachowicz, J.E.; Wang, Y. and Liu, S. (2005). RNA interference targeting of A1 receptor-overexpressing breast carcinoma cells leads to diminished rates of cell proliferation and induction of apoptosis. Cancer Biol Ther, Vol. 4, No. 12, pp. 1355-1360.

Montesinos, M.C.; Gadangi, P.; Longaker, M.; Sung, J.; Levine, J.; Nilsen, D.; Reibman, J.; Li, M.; Jiang, C.K.; Hirschhorn, R.; Recht, P.A.; Ostad, E.; Levin, R.I. \& Cronstein, B.N. (1997). Wound healing is accelerated by agonists of adenosine $A_{2}$ (G alpha s-linked) receptors. J Exp Med, Vol. 186, No. 9, pp. 1615-1620.

Montesinos, M.C.; Desai, A.; Chen, J.F.; Yee, H.; Schwarzschild, M.A.; Fink, J.S. and Cronstein B.N. (2002). Adenosine promotes wound healing and mediates angiogenesis in response to tissue injury via occupancy of A2A receptors. Am J Pathol Vol. 160, No. 6, pp. 2009-2018.

Morello, S.; Sorrentino, R.; Montinaro, A.; Luciano, A.; Maiolino, P.; Ngkelo, A.; Arra, C.; Adcock, I.M. \& Pinto, A. (2011). NK1.1+ cells and CD8+T cells mediate the antitumour activity of Cl-IB-MECA in a mouse melanoma model. Neoplasia, Vol. 13, No. 4, pp. 365-373.

O’Day, S.J.; Kim, C.J. \& Reintgen, D.S. (2002). Metastatic melanoma: chemotherapy to biochemotherapy. Cancer Control, Vol. 9, No. 1, pp. 31-38.

Offner, F.A.; Wirtz, H.C.; Schiefer, J.; Bigalke, I.; Klosterhalfen, B.; Bittinger, F.; Mittermayer, C. \& Kirkpatrick, C.J. (1992). Interaction of human malignant melanoma (ST-ML12) tumor spheroids with endothelial cell monolayers. Damage to endothelium by oxygen-derived free radicals. Am J Pathol, Vol. 141, No. 3, pp. 601-610.

Offner, F.A.; Schiefer, J.; Wirtz, H.C.; Bigalke, I.; Pavelka, M.; Hollweg, G.; Ensinger, C.; Klosterhalfen, B.; Mittermayer, C. \& Kirkpatrick, C.J. (1996). Tumour-cellendothelial interactions: free radicals are mediators of melanoma-induced endothelial cell damage. Virchows Arch, Vol. 428, No. 2, pp. 99-106.

Ohana, G.; Bar-Yehuda, S.; Arich, A.; Madi, L.; Dreznick, Z.; Rath-Wolfson, L.; Silberman, D.; Slosman, G., \& Fishman, P. (2003) Inhibition of primary colon carcinoma growth and liver metastasis by the $\mathrm{A}_{3}$ adenosine receptor agonist CF101. Br J Cancer, Vol. 89, No. 8, pp. 1552-1558.

Ohta, A.; Gorelik, E.; Prasad, S.J.; Ronchese, F.; Lukashev, D.; Wong, M.K.; Huang, X.; Caldwell, S.; Liu, K.; Smith, P.; Chen, J.F.; Jackson, E.K.; Apasov, S.; Abrams, S. \& Sitkovsky, M. (2006). A2A adenosine receptor protects tumors from antitumor T cells. Proc Natl Acad Sci USA, Vol. 103, No. 35, pp. 13132-13137.

Okada, F.; Kobayashi, M.; Tanaka, H.; Kobayashi, T.; Tazawa, H.; Iuchi, Y.; Onuma, K.; Hosokawa, M.; Dinauer, M.C. \& Hunt, N.H. (2006). The role of nicotinamide adenine dinucleotide phosphate oxidase-derived reactive oxygen species in the acquisition of metastatic ability of tumor cells. Am J Pathol, Vol. 169, No. 1, pp. 294302.

Panjehpour, M.; Castro, M. \& Klotz, K.N. (2005). Human breast cancer cell line MDA-MB231 expresses endogenous $\mathrm{A}_{2 \mathrm{~B}}$ adenosine receptors mediating a $\mathrm{Ca}^{2+}$ signal. $\mathrm{Br}$ J Pharmacol, Vol. 145, No. 2, pp. 211-218. 
Patel, J.K.; Didolkar, M.S.; Pickren, J.W. \& Moore, R.H. (1978). Metastatic pattern of malignant melanoma. A study of 216 autopsy cases. American Journal of Surgery, Vol. 135, No. 6, pp. 807-810.

Phelps, P.T.; Anthes, J.C. \& Correll, C.C. (2006). Characterization of adenosine receptors in the human bladder carcinoma T24 cell line. Eur J Pharmacol, Vol. 536, No. 1-2, pp. 28-37.

Poetsch, M.; Dittberner, T.; Petersmann, A. \& Woenckhaus, C. (2004). Mitochondrial DNA instability in malignant melanoma of the skin is mostly restricted to nodular and metastatic stages. Melanoma Res, Vol. 14, No. 6, pp. 501-508.

Qin, Z. \& Blankenstein, T. (2000). CD4+ T cell--mediated tumor rejection involves inhibition of angiogenesis that is dependent on IFN gamma receptor expression by nonhematopoietic cells. Immunity, Vol. 12, No. 6, pp. 677-686.

Raskovalova, T.; Huang, X.; Sitkovsky, M.; Zacharia, L.C.; Jackson, E.K. \& Gorelik, E. (2005). Gs protein-coupled adenosine receptor signaling and lytic function of activated NK cells. J Immunol, Vol. 175, No. 7, pp. 4383-4391.

Raskovalova, T.; Lokshin, A.; Huang, X.; Su, Y.; Mandic, M.; Zarour, H.M.; Jackson, E.K. \& Gorelik, E. (2007). Inhibition of cytokine production and cytotoxic activity of human antimelanoma specific CD8+ and CD4+ T lymphocytes by adenosineprotein kinase A type I signaling. Cancer Res, Vol. 67, No. 12, pp. 5949-5956.

Rudolphi, K.A.; Schubert, P.; Parkinson, F.E. \& Fredholm, B.B. (1992). Adenosine and brain ischemia. Cerebrovasc Brain Metab Rev, Vol. 4, No. 4, pp. 346-369.

Ryzhov, S.; Novitskiy, S.V.; Zaynagetdinov, R.; Goldstein, A.E.; Carbone, D.P.; Biaggioni, I.; Dikov, M.M. \& Feoktistov, I. (2008). Host A(2B) adenosine receptors promote carcinoma growth. Neoplasia, Vol. 10, No. 9, pp. 987-995.

Saito, M.; Yaguchi, T.; Yasuda, Y.; Nakano, T. \& Nishizaki, T. (2010). Adenosine suppresses CW2 human colonic cancer growth by inducing apoptosis via $\mathrm{A}_{1}$ adenosine receptors. Cancer Lett, Vol. 290, No. 2, pp. 211-215.

Schulte, G. \& Fredholm, B.B. (2000). Human adenosine $A_{1}, A_{2 A}, A_{2 B}$, and $A_{3}$ receptors expressed in Chinese hamster ovary cells all mediate the phosphorylation of extracellular-regulated kinase 1/2. Mol Pharmacol, Vol. 58, No. 3, pp. 477-82.

Seftor, E.A.; Brown, K.M.; Chin, L.; Kirschmann, D.A.; Wheaton, W.W.; Protopopov, A.; Feng, B.; Balagurunathan, Y.; Trent, J.M.; Nickoloff, B.J.; Seftor, R.E. \& Hendrix, M.J. (2005). Epigenetic transdifferentiation of normal melanocytes by a metastatic melanoma microenvironment. Cancer Res, Vol. 65, No. 22, pp. 10164-10169.

Serrano, M.; Hannon, G.J. \& Beach, D. (1993). A new regulatory motif in cell-cycle control causing specific inhibition of cyclin D/CDK4. Nature, Vol. 366, No. 6456, pp. 704707.

Sexl, V.; Mancusi, G.; Höller, C.; Gloria-Maercker, E.; Schütz, W., \& Freissmuth, M. (1997) Stimulation of the mitogen-activated protein kinase via the A2A-adenosine receptor in primary human endothelial cells. J Biol Chem, Vol. 272, No. 9, pp. 57925799 .

Shankaran, V.; Ikeda, H.; Bruce, A.T.; White, J.M.; Swanson, P.E.; Old, L.J. \& Schreiber, R.D. (2001). IFNgamma and lymphocytes prevent primary tumour development and shape tumour immunogenicity. Nature, Vol. 410, No. 6832, pp. 1107-1111.

Sober, A.J.; Tsao, H. \& Washington, C.V. (2008). Cancer of the Skin. Harrison's: Principles of Internal Medicine (17th Ed.), McGraw Hill Medical, New York. 
Su, Y.; Huang, X.; Raskovalova, T.; Zacharia, L.; Lokshin, A.; Jackson, E. \& Gorelik, E. (2008). Cooperation of adenosine and prostaglandin E2 (PGE2) in amplification of cAMPPKA signaling and immunosuppression. Cancer Immunol Immunother, Vol. 57, No. 11, pp. 1611-1623.

Su, Y.; Jackson, E.K. \& Gorelik, E. (2011). Receptor desensitization and blockade of the suppressive effects of prostaglandin $\mathrm{E}(2)$ and adenosine on the cytotoxic activity of human melanoma-infiltrating T lymphocytes. Cancer Immunol Immunother, Vol. 60, No. 1, pp. 111-122.

Synnestvedt, K.; Furuta, G.T.; Comerford, K.M.; Louis, N.; Karhausen, J.; Eltzschig, H.K.; Hansen, K.R.; Thompson, L.F., \& Colgan, S.P. (2002) Ecto-5'-nucleotidase (CD73) regulation by hypoxia-inducible factor-1 mediates permeability changes in intestinal epithelia. J Clin Invest, Vol. 110, No. 7, pp. 993-1002.

Synowitz, M.; Glass, R.; Färber, K.; Markovic, D.; Kronenberg, G.; Herrmann, K.; Schnermann, J.; Nolte, C.; van Rooijen, N.; Kiwit, J. \& Kettenmann, H. (2006). A1 adenosine receptors in microglia control glioblastoma-host interaction. Cancer Res, Vol. 66, No.17, pp. 8550-8557.

van der Bruggen, P.; Traversari, C.; Chomez, P.; Lurquin, C.; De Plaen, E.; Van den Eynde, B.; Knuth, A. \& Boon, T. (1991). A gene encoding an antigen recognized by cytolytic T lymphocytes on a human melanoma. Science, Vol. 254, No. 5038, pp. 1643-1647.

Weber, J. (2011). Immunotherapy for melanoma. Curr Opin Oncol, Vol. 23, No. 2, pp. 163-169.

Wen, P.Y.; Black, P.M. \& Joeffler, S.L. (2001). Treatment of metastatic cancer. Cancer: principles and practice of oncology (6), Lippincott, Williams \& Wilkins, Philadelphia, pp. 2655-2670.

Wick, M.R.; Swanson, P.E. \& Rocamora, A. (1988). Recognition of malignant melanoma by monoclonal antibody HMB-45. An immunohistochemical study of 200 paraffinembedded cutaneous tumors. J Cutan Pathol, Vol. 15, No. 4, pp. 201-207.

Woodhouse, E.C.; Amanatullah, D.F.; Schetz, J.A.; Liotta, L.A.; Stracke, M.L. \& Clair, T. (1998). Adenosine receptor mediates motility in human melanoma cells. Biochem Biophys Res Commun, Vol. 246, No. 3, pp. 888-894.

Xaus, J.; Mirabet, M.; Lloberas, J.; Soler, C.; Lluis, C.; Franco, R., \& Celada, A. (1999) IFNgamma up-regulates the $A_{2 B}$ adenosine receptor expression in macrophages: a mechanism of macrophage deactivation. J Immunol, Vol. 162, No. 6, pp. 3607-3614.

Yamaura, M.; Mitsushita, J.; Furuta, S.; Kiniwa, Y.; Ashida, A.; Goto, Y.; Shang, W.H.; Kubodera, M.; Kato, M.; Takata, M.; Saida, T. \& Kamata, T. (2009). NADPH oxidase 4 contributes to transformation phenotype of melanoma cells by regulating G2-M cell cycle progression. Cancer Res, Vol. 69, No. 6, pp. 2647-2654.

Yasuda, Y.; Saito, M.; Yamamura, T.; Yaguchi, T. \& Nishizaki, T. (2009) Extracellular adenosine induces apoptosis in Caco-2 human colonic cancer cells by activating caspase-9/-3 via A(2a) adenosine receptors. J Gastroenterol, Vol. 44, No. 1, pp 56-65.

Yoshikawa, N.; Yamada, S.; Takeuchi, C.; Kagota, S.; Shinozuka, K.; Kunitomo, M. \& Nakamura, K. (2008). Cordycepin (3'-deoxyadenosine) inhibits the growth of B16BL6 mouse melanoma cells through the stimulation of adenosine A3 receptor followed by glycogen synthase kinase-3beta activation and cyclin D1 suppression. Naunyn Schmiedebergs Arch Pharmacol, Vol. 377, No. 4-6, pp. 591-595.

Zamai, L.; Ponti, C.; Mirandola, P.; Gobbi, G.; Papa, S.; Galeotti, L.; Cocco, L. \& Vitale, M. (2007). NK cells and cancer. J Immunol, Vol. 178, No. 7, pp. 4011-4016. 
Zhang, H.; Conrad, D.M.; Butler, J.J.; Zhao, C.; Blay, J. \& Hoskin, D.W. (2004). Adenosine acts through A2 receptors to inhibit IL-2-induced tyrosine phosphorylation of STAT5 in T lymphocytes: role of cyclic adenosine 3',5'-monophosphate and phosphatases. J Immunol, Vol. 173, No. 2, pp. 932-944.

Zhao, Y.; Liu, J. \& McMartin, K.E. (2008). Inhibition of NADPH oxidase activity promotes differentiation of B16 melanoma cells. Oncol Rep, Vol. 19, No. 5, pp. 1225-1230.

Zeng, D.; Maa, T.; Wang, U.; Feoktistov, I. Biaggioni, I. \& Belardinelli, L. (2003). Expression and function of $\mathrm{A}_{2 \mathrm{~B}}$ adenosine receptors in the U87MG tumor cells. Drug Development Research, Vol. 58, No. 4, pp. 405-411. 


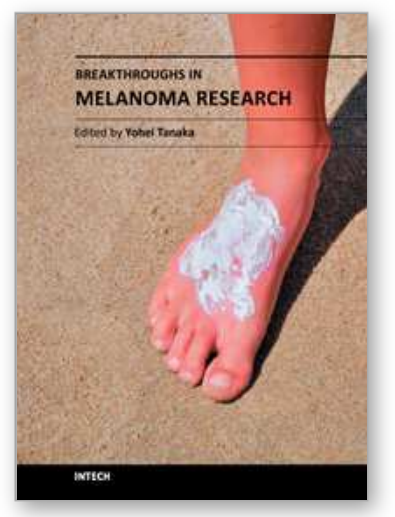

\author{
Breakthroughs in Melanoma Research \\ Edited by Dr Yohei Tanaka
}

ISBN 978-953-307-291-3

Hard cover, 628 pages

Publisher InTech

Published online 30, June, 2011

Published in print edition June, 2011

Melanoma is considered to be one of the most aggressive forms of skin neoplasms. Despite aggressive researches towards finding treatments, no effective therapy exists to inhibit the metastatic spread of malignant melanoma. The 5-year survival rate of metastatic melanoma is still significantly low, and there has been an earnest need to develop more effective therapies with greater anti-melanoma activity. Through the accomplishment of over 100 distinguished and respected researchers from 19 different countries, this book covers a wide range of aspects from various standpoints and issues related to melanoma. These include the biology of melanoma, pigmentations, pathways, receptors and diagnosis, and the latest treatments and therapies to make potential new therapies. Not only will this be beneficial for readers, but it will also contribute to scientists making further breakthroughs in melanoma research.

\title{
How to reference
}

In order to correctly reference this scholarly work, feel free to copy and paste the following:

Sarvesh Jajoo, Sandeep Sheth, Debashree Mukherjea, Leonard P. Rybak and Vickram Ramkumar (2011). Targeting Adenosine Receptors for the Treatment of Melanoma, Breakthroughs in Melanoma Research, Dr Yohei Tanaka (Ed.), ISBN: 978-953-307-291-3, InTech, Available from:

http://www.intechopen.com/books/breakthroughs-in-melanoma-research/targeting-adenosine-receptors-forthe-treatment-of-melanoma

\section{INTECH}

open science | open minds

\section{InTech Europe}

University Campus STeP Ri

Slavka Krautzeka 83/A

51000 Rijeka, Croatia

Phone: +385 (51) 770447

Fax: +385 (51) 686166

www.intechopen.com

\section{InTech China}

Unit 405, Office Block, Hotel Equatorial Shanghai

No.65, Yan An Road (West), Shanghai, 200040, China 中国上海市延安西路65号上海国际贵都大饭店办公楼 405 单元 Phone: +86-21-62489820

Fax: $+86-21-62489821$ 
(C) 2011 The Author(s). Licensee IntechOpen. This is an open access article distributed under the terms of the Creative Commons Attribution 3.0 License, which permits unrestricted use, distribution, and reproduction in any medium, provided the original work is properly cited. 